The mangrove has established itself on the edges of the lagoon, doubtless from seed transported by the currents, and, in all places where it has done so, tortuous creeks or little gorges run back into the coral, filled with mangrove trees (standing in deep mud of the adhesive and fotid nature so characteristic of mangrove swamps), which stretch out their roots to the coral walls around them, and, as it seemed indubitably to me, in some way decompose the softer parts and eat their way in. The island is riddled with these creeks, always filled with mangrove, and opening into the lagoon.

The outer face of the island is of courie being slowly undermined by the sea at high water, presenting overhanging cliffs impossible to scale, and the island is wearing away from that cause also, but the destruction from the mangrove is much more important, and at no very distant period, as it seemed to me, the upraised island will be again reduced to its original level as an ordinary atoll.

It would be interesting to know how long the mangrove has been there, for as Aldabra is one of the two oceanic groups in which the giant tortoises still exist indigenous, it must have been in its present condition of upraised atoll, I imagine, for a long period. It could never have been much larger in diameter, from the soundings round it, but the mangrove may have greatly increased the size of the lagoon by steady working at the inner rim of the islands, the actual area of wbich is now but small, from their narrowness.

I may mention that the island is covered with low, tangled scrub, which has managed to find foothold anrl sustenance on the rock, for there is but little or no soil, and the top of the rock is everywhere cut up by sub-aërial action into the sharp, honeycombed, and jagged surface which upraised coral in the tropics, uncovered by grasses, soil, \&c., always wears inio, and which, by the way, makes it extremely difficult to walk over, a difficulty much increased in this instance by these mangrove channels, as well as the tough nature of the matted, thorny bushes. A walk in Aldabra is the most aggravating and slowest piece of locomotion I have ever engaged in : and nothing short of the patience, perseverance, and general disregard of time of the tortoise tribe can make it an agreeable residence. Some of my negro sailors were sent into the bush to hunt for tortoises, and after three days' search brought back one, which is now in the Gardens of the Zoologica! Society ; but they returned nearly as guiltless of artificial clothing as their captive.

H.M.S. Sylvia, Monte Video, October 10 W. J. L. WHARTON

\section{The "Cloud-Glow" of November 9}

THE beautiful after-glow of Friday, the $9^{\text {th }}$ instant, was most striking as seen from the west side of Hampstead Hill, where it. fi: st development was made more effective by a frame of dark cumulus, with a fringe of dusky green tint, carried up from the sunset quarter by a westerly breeze, rather rolled up like a curtain, exhibiting the richly-coloured scene behind as it was withdrawn. I estimated the altitude of the upper edge of the glow at about $30^{\circ}$; but at Freshwater, Isle of Wight, it has been described as extending nearly to the zenith. There would be no difficulty in calculating apprsximately the height of the cirrus as desired by Mr. Kussell-if it could be assumed that the reflection was from the same matter in both cases, which is improbable.

J. J. WAI KER

\section{Waking Impressions}

A curious case $I$ have just read in a recent number of NATURE recalls a somewhat similar experience of my own, rather earlier in date. I awoke in the mirdle of a story told by an internal voice-a voice felt, not heard. I listened with curiosity and interest, as totally unprepared for what was coming as if the narrator had been Gladstone or Ruskin. I believe when I awoke I had a dim recollection of what had gone before, but I strove afterwards in vain to recall it. All I know of the history of the mysterious lady is the following fragment: "She had many admirers, but she gave the preference to 'Tom, because he promised to marry her in the West Indian fashion. He drew her three times through a hoop, once standing, once sitting, once lying, which signified that he would never de ert her in youth, maturity, or old age."

I have not the least idea who "she" was. I know no one I call Tom except an old schoolfellow long married, and, to the best of my belief, I never heard of such a custom in the West Indies or elsewhere. Once since I have waked in the middle of a dream which went on, but it was a dream of a very commonplace character.

WILLIAM RADFORD

Sidmouth

\section{Barytes from Chirbury}

I AM indebted to $\mathrm{Mr}$. Yelland of Wotherton for sending me some fine examples of the crystals described by Mr. Miers in NATURE, vol xxix. p. 29, and am collecting several particulars respecting their occurrence. Some time ago I commenced a determination of the faces, but my work has been interrupted.

The characteristic plane E is mentioned by Carl Urba (Groth, Zeitschrift fïr Crystallographie, v. 433, 1881) as occurring on barytes crystals from Swoszawice in Galizien. In a measurement I nade last year to determine this plane on one of the Wotherton specimens I obtained $\mathrm{EE}^{\prime}$ as $39^{\circ} 59^{\prime}$, and, using Miller's distance for $b d$ leads to the symbol $4 \mathbf{I} 2$, and by calculation the distance $a \mathrm{E}$ as $26^{\circ} 2^{\prime}$. Carl Urba gives its calculated distance as $26^{\circ} 4^{\prime}$, and measured distance as $25^{\circ} 58^{\circ}$.

Birmingham and Midland Institute, Birmingham, Nov. Io

\section{"Salt Rain and Dew"}

Looking over the "School Geography" of Dr. Clyde (Edin. burgh, 1870 ), I find, on page 32 , in the paragraph headed "Russian Lalies," the following remarkable statement:-"In the south-east region, not only the lakes, but the very rain and derv liktreise are salt, a phenomenon common to all the shores of the Caspian and Sea of Aral" (the italics are mine). Will some one of your readers kindly refer me to the traveller's tale in which this myth originated.

Esterel, Temple Road, Dublin, Novemlier I7.

\section{AN INDIAN WEATHER FORECAST}

THE period of drought in Upper India, which happily came to an end in the latter part of August, was not entirely unforeseen, as will be shown by the following extracts from the Government Gazette; and the facts will probably be not without interest to meteorologists in Europe and elsewhere.

\section{Extract from the "Gazette of India" of June 2, I 883}

"That the unusually dry weather now prevailing over the North-Western Himalaya, and that which, though less abnormal, characterises the whole of North-Western India at the present time, is an effect of the unusual accumulation of snow, is a conclusion justified by the experience of the last few years; and were it not that the snow is rapidly decreasing under the unobstructed radiation of the sun, there might be some reason, judging from the present limited experience, to anticipate some retardation of the rains of the Upper Provinces, and possibly even in Western India generally. But, on the other hand, the fact that, during the months of April and May, the atmospheric pressure over the greater part of the country lias been below the normal average of the season, is one which, arguing from the same experience, portends favourably for the timely influx of the monsoon. In Bengal it may be said that the present prospects are wholly favourable.

$$
\text { (Signed) "HENRY F. BLANFORD, }
$$
Meteorological Reporter to the

\section{"Simla, May I 8 , I 883 "} Government of India

"Since the above was written, there bas been heavy rain for many days on the outer hills, and more or less on the plains of the Punjab, and apparently a very heavy fall of snow on the higher ranges. At the present time, as seen from Simla, the latter are white with snow, down to a level of about 11,000 or 12,000 feet. And some 500 feet of the top of the Chor ( 11,982 feet) is also covered with a snowcap. If, therefore, the mountains of Lalwul, Spiti, and 
other more distant ranges have shared this fall, if it is as extensive as it is apparently heavy on the visible ranges, and if the views which the experience of recent years seems to justify, viz. that an unusual extent and thickness of snow on the Himalaya is productive of dry north-west and west winds in North-Western India, are valid, we must be prepared for a long spell of dry weather and a retarded rainfall in the Upper Provinces. The present season will serve as a test of the validity of the above view.

\section{(Signed) "HENRY F. BLANFORD,} Meteorological Reporter to the Government of India

\section{"Simla, May 31, 1883"}

Information was subsequently received to the effect that the heavy snow of the winter months as well as that which fell at the end of May was restricted to the outer range. In the interior of Lalwul and Spiti and in the Pangi valley the snowfall was very deficient. Nevertheless the May fall on the outer range seems to have sufficed to produce the effect predicted.

Extracts from a Memorandum on the Chief Weather Characteristics of the Month of June, 1883, in India, in the "Gazette of India"

"In Bengal, after some weeks of close cloudy weather, with occasional showers, the monsoon rains were ushered in on June I3, with a little cyclonic storm, formed apparently on the coast of the Sunderbuns. From the coast on the three following days this storm passed inland, on a north-west course, bringing heavy rain in its track, as far west as Behar, and a moderate fall up to Allahabad; beyond which, for a time, the rains did not advance. . . At Bombay it blew strongly on the IIth, 12 th, and I 3 th, but not from the monsoon quarter; and afterwards the wind fell light, and so continued till the $24 \mathrm{th}$, when the monsoon set in steadily. But the rainfall has been light throughout the month, and, at its close, was six inches short of the normal average. On the 26 th or 27 th a second cyclone was formed at the head of the Bay of Bengal, causing heavy rain around the coasts, and especially those of Orissa and Ganjam; then, travelling westward, the centre reached Cuttack on June 30 ; Seoni on July I ; Indore on the 2nd; and lay between Kurrachee and Rajkot on the 3 rd. It caused very heavy rain in Gujerat, flooding the rivers, and interrupting railway communication between Bombay and Baroda.

"In the North-Western Provinces, with the exception already mentioned, the rains did not set in before the $26 \mathrm{th}$, but throughout the month the wind was, in general, easterly, and occasional thunderstorms occurred. In the Funjab also, the first rain fell between the 26 th and 29 th, but in the eastern half of the province the prevailing high tempcrature was mitigated by an occasional duststorm. . . .

"In Lower Bengal rain of importance fell on twentytwo days. The total fall of the month was five inches in excess. ...

"In Rajputana, Sind, \&c., the number of days on which rain fell was only four, and the average total was less by three-quarters of an inch than even the small amount which generally falls in this region in the month of June. ...

"From the above it appears that, over a large tract of country, the monsoon so far bas been weak. On May 28 it was reported to have burst at Cochin; and between that date and June 5 it appears to have spread along that coast as far north as Goa. In Bombay itself the weather has been showery, but there have been no very heavy falis of rain. On the Bengal side, on the contrary, the south and south-west winds have brought up even more than the normal amount of rain, and the weather at the head of the Bay has been somewhat exceptionally rough
In Northern India the monsoon current has been much delayed, and in parts of the North-Western Provinces and the Punjab continuous rain has hardly yet set in.

$$
\begin{gathered}
\text { (Signed) "W. L. DALLAS, } \\
\text { Assistant Meteorological Reporter } \\
\text { to the Government of India" }
\end{gathered}
$$

\section{Extracts from a Memorandum on the Chief Weather Characteristics of July, 1883, in India, in the "Gazette of India"}

"Except in the North-Western and at a few Central stations, the rainfall of the month shows on the whole comparatively little departure from the average.

"After the disappearance of the storm noticed in the June summary, which passed from the Bay of Bengal across India, \&c., . . . there occurred a general rise of the barometer, a corresponding decrease in the humidity of the atmosphere, and a cessation of the rainfall, over a large tract of country for two or three days. On the 5 th or 6th, however, rain recommenced generally and continued for some time. In the eastern half of the NorthWestern Provinces, Assam, Bengal, Burmah, and the south of the peninsula, it fell more or less on every day, till the close of the month, but over Western and North-Western India the fall ceased about the rgth, and from that date till the end of the month a decided break in the rains occurred, and fine weather set in.

"On the plains of the Punjab there were only eleven wet days; the break in the rains, which commenced on the 19 th, being very decided in this province. In consequence the amount of rain for the montb, and, except in the Indus valley, the total since June $\mathrm{I}$, was several inches below the average. ...

"The weather in the western half of the North-Western Provinces was similar to that experienced in the Punjab, but in the eastern half it was wetter, the number of rainy days being nineteen. In the Meerut division five inches less than the average amount fell during the month; while at Lucknow eight inches and at Allahabad one and a half inches more than the average was registered. . . .

"In Lower Bengal and parts of Behar the rainfall was several inches above the July average; while in Purneah, Patna, and Orissa it was deficient. The average number of wet dajs was twenty-six, and no break in the rains of any consequence occurred within these provinces. . .

"In Rajputana the rainfall was about the average amount, and occurred on thirteen days; scarcely any fell after the $i 7$ th. ...

$$
\begin{gathered}
\text { (Signed) "W. L. DalLAS, } \\
\text { Assistant Meteorological Reporter } \\
\text { to the Government of India" }
\end{gathered}
$$

\section{Extract from a Memorandum of the Chief Weather Characteristics of August, I883, in the "Gasette of India"}

"The month just elapsed was one of very deficient rainfall throughout India, except in the provinces of Madras, Berar, and Assam. The break in the rains, which during the latter half of July was very general in North-Western and parts of Central India, became even more pronounced throughout that region during the first three weeks of the month under review; and extended, though in a modified degree, to Behar and a large part of Bombay. The drought was apparently at its height, both as regards extent and intensity, during the second week in August. ... On the Igth, however, a change commenced. The air became slowly damper over the Central and North-Western Provinces, and the sky more cloudy; and very gradually these changes spread, till at the close of the month rain had extended to the Punjab, Rajputana, and Gujerat ; in Rajputana and a large part of the Punjab and the North-Western Provinces it was only on the last 
two days of the month that rain began to fall, and even then in small amounts. . . .

$$
\begin{gathered}
\text { (Signed) "W. L. DaLLAS, } \\
\text { Assistant Meteorological Reporter } \\
\text { to the Government of India" }
\end{gathered}
$$

The above extracts speak for themselves. The results do not accord precisely with the terms of the prediction, inasmuch as the rains, instead of being simply retarded, penetrated for about a fortnight to the Upper Provinces, and then gave place to the dry north-west winds, which are characteristic of periods of drought. But there is no reason to regard the snows as inactive during this rainy interval. At Simla this rainy period was one of frequent thunderstorms and on more than one occasion of hail, 1 and in fine intervals the existence overhead of the ominous north-west wind was established by the steady drift of the higher clouds (cirro-cumulus, \&c.). The outflow of dense air from the snow-fields was therefore active, although it was only at a later period that it descended to the leve of the lower hills; and then, chiefly as the result of diurnal convection, to the plains of North-Western India

The full discussion of the evidence for the dependence of dry winds on the snowfall will be undertaken elsewhere. It must not, however, be supposed that the Himalayan snows are to be regarded as the sole cause of drought. Causes of wider incidence are sometimes in operation. Thus, in 1876 and 1877 , an unusually high atmospheric pressure prevailed over nearly the whole of Asia and Australia. Whether there was any unusual accumulation of snow on the vast mountain tracts of Central Asia or over the northern plains in those years would be an interesting subject of inquiry were the means of information forthconing.

H. F. B.

\section{NORDENSKJÜLD'S GREENLAND EXPEDITION2}

\section{III.}

WE give a few extracts from Baron Nordenskjöld's concluding letters on his journey down the west coast of Greenland and his visit to the east coast :-

At Ivigtut a visit was made to a valley which, on account of its copious flora, has been named Grönnedal (Green valley), and another to the spot where the inland ice falls into the Arsukfjord. In the former place Dr. Nathorst found, in a kind of syenite, a blue mineral which seems to be sodalite. This discovery is chiefly remarkable from the circumstance that this mineral is also found in the vicinity of the small kryolite deposit at the Ilmen mountain in the Ural, which seems to indicate that a kind of relation exists between these two minerals, both strong in natron, which circumsiance may be of service to the geologist in search of kryolite. From the excursion to Grönnedal Herr Kolthoff brought with him some rare butterflies and other insects, while of the botanical finds there were splendid specimens in bloom of Linncea borealis, which is quite plentiful about Ivigtut. It bas not before been known to exist in Greenland. The zoologists found only three kinds of land mollusks, viz. a physa, a vitrina, and a helix, which were all few in number. The entomological harvest consisted of a few beetles, butterflies, and insects of other kinds.

On their way to Julianehaab, as they steamed down the narrow fjord in pitch darkness and a perfect calm, "we saw suddenly behind the vessel on the surface of the sea a broad but clearly defined band of light. It shone with a steady, yellowish light, somewhat like that of phosphorescent elements, while, in spite of the speed maintained, viz. four to six knots, the band came nearer and nearer. When it reached the ship it seemed as if we

I These accompaniments are characteristic of the spring rainfall both $\mathrm{cn}$ the hills and the plains, not of the monsocn rains, and indicate demonstrably in most cases the existence of a dry upper current.

${ }^{2}$ Continued from p. 42 were steaming through a sea of fire or molten metal. After a while the light travelled beyond the vessel, and we saw it at last disappear on the horizon. Unfortunately I had not an opportunity of examining it with the spectroscope. It was beyond doubt of a different nature to the bluish-white phosphorescent light, which throughout its appearance was seen distinctly in our wake, and as the light was perfectly steady it cannot have been caused by the phosphorescence from a passing shoal of fish. A shoal of fish would have occasioned some stir in the sea, but in this case the surface was calm throughout, while phosphorescence from the same would have been bluish in character, not yellow as this was. The Esquimaux stated that a glacier river in the vicinity shed a thin layer of brackish clay-water over the surface of the fjord, and fancied that this circumstance was in some way or another connected with this grand phenomenon, which they themselves had never before witnessed. There was at the time no aurora visible, the sky being covered with clouds. The cause of this remarkable phenomenon, which made the Sophic seem to steam through a sea of fire for fully fifteen minutes, I have been unable to ascertain; maybe it was a phenomenon such as this which made LigLodin, of the Greenland Saga, relate to King Haraid Sigurdson that he had once sailed over a spot where the sea was on fire."

At Fredriksdal Nordenskjöld engaged two Esquimaux to act as pilots in the sounds on the east coast, north of Cape Farewell. One of them stated that remains of buildings, which were not built by the Esquimaux, are to be found in nearly every great fjord on the east coast, particularly in the large ones of Umanak, Ekaleumiut, and Igdluluarsiut. Entire walls do not remain standing, but though low they are extensive. The largest ruin is said to exist at Igdluluarsiut. A fine kind of soft stone is to be found on an island south of Umanak, from which pots were made to three feet in diameter. This mineral deposit is of special interest in reference to the ethnography of Greenland, as the Umanak fjord is situated in lat. $63^{\circ}$. This name is, however, a common one for places among the natives. Ivar Baardsen, in his famous description of Greenland, states that a soft stone was found on Renö, outside the Einafjord, from which the largest vessels were made. Cannot the mineral deposit at Umanak be identical with this? These statements, as well as others received from the "Eastlanders," and the remarkab?e Norse characteristics possessed by the same, which the missionary Hans Egede pointed out long ago, seem to Baron Nordenskjöld to refute the theory now mostly advanced as to the Norse colonies, viz. that they were situated on the south-west coast of Greenland.

In spite of predictions of failure and even disaster before he left Europe, Nordenskjöld decided to attempt to land on the east coast, south of the Arctic circle. After some difficulty they succeeded in anchoring in the Kangerlutsiok Bay, but on account of the state of the ice they had to stand to sea again, and steamed along the ice-belt lining the coast, in order to find an opening by which the shore might be reached. The fauna of the sea here was very poor, and they only saw in two days one whale, a few seals, and a very small number of sea birds. The abundant fauna of the coasts of Spitzbergen and Novaya Zemlya is thus entirely wanting on the east coast of Greenland. The cause of this may be the great depth of the sea right up to the shore, which prevents the animals from fetching their food from the bottom ; perhaps also the war of extirpation which the natives seem to have carried on for years has also contributed thereto. The auk and the Uria grylle are, however, said to breed in large numbers on the rocks off Cape Farewell. The Esquimaux pilot stated that he had been told by old people that they could remember the Alka impennis having been found here. The natives called it Isaro- 